8. Mosmann TR, Sad S. The expanding universe of T-cell subsets: Th1, Th2 and more. Immunol Today 1996; 17: 138-146.

9. Barnes PJ. Anti-IgE antibody therapy for asthma [editorial; comment]. $N$ Engl J Med 1999; 341: 2006-2008.

10. de Vries JE, Carballido JM, Aversa G. Receptors and cytokines involved in allergic TH2 cell responses. J Allergy Clin Immunol 1999; 103 S492-S496.

11. Holt PG, Sly PD. Prevention of adult asthma by early intervention during childhood: potential value of new generation immunomodulatory drugs. Thorax 2000; 55: 700-703.

12. Strachan DP. Family size, infection and atopy: the first decade of the 'hygiene hypothesis'. Thorax 2000; 55 (Suppl 1): S2-S10.

13. Holt PG, Stumbles PA. Regulation of immunologic homeostasis in peripheral tissues by dendritic cells: the respiratory tract as a paradigm J Allergy Clin Immunol 2000; 105: 421-429.

14. Stumbles PA, Thomas JA, Pimm CL, Lee PT, Venaille TJ, Proksch S, Holt PG. Resting respiratory tract dendritic cells preferentially stimulate $T$ helper cell type 2 (Th2) responses and require obligatory cytokine signals for induction of Th1 immunity. $J$ Exp.Med 1998; 188: 2019-2031.

15. Spiteri MA, Knight RA, Jeremy JY, Barnes PJ, Chung KF. Alveolar macrophage-induced suppression of peripheral blood mononuclear cell responsiveness is reversed by in vitro allergen exposure in bronchial asthma. Eur Resp J 1994; 7: 1431-1438.

16. Haczku A, Takeda K, Redai I, et al. Anti-CD86 (B7.2) treatment abolishes allergic airway hyperresponsiveness in mice. Am J Respir Crit Care Med 1999; 159: 1638-1643.

17. Van Oosterhout AJ, Hofstra CL, Shields R, Chan B, van Ark I, Jardieu PM Nijkamp FP. Murine CTLA4-IgG treatment inhibits airway eosinophilia and hyperresponsiveness and attenuates IgE upregulation in a murine model of allergic asthma. Am J Respir Cell Mol Biol 1997; 17 386-392.

18. van Neerven RJ, Van de Pol MM, van der Zee JS, Stiekema FE, De Boer M Kapsenberg ML. Requirement of CD28-CD86 costimulation for allergenspecific $\mathrm{T}$ cell proliferation and cytokine expression [see comments] Clin Exp Allergy 1998; 28: 808-816.

19. Devalia JL, Davies RJ. Airway epithelial cells and mediators of inflammation. Resp Med 1993; 6: 405-408.

20. Saunders MA, Mitchell JA, Seldon PM, Barnes PJ, Giembycz MA, Belvisis MG. Release of granulocyte-macrophage colony-stimulating factor by human cultured airway smooth muscle cells: suppression by dexamethasone. Br J Pharmacol 1997; 120: 545-546.

21. Chung KF, Barnes PJ. Cytokines in asthma. Thorax 1999; 54: 825-857.

22. Corry DB, Kheradmand F. Induction and regulation of the IgE response. Nature 1999; 402: B18-B23

23. Borish LC, Nelson HS, Lanz MJ, Claussen L, Whitmore JB, Agosti JM, Garrison L. Interleukin-4 receptor in moderate atopic asthma. A phase I/II randomized, placebo-controlled trial. Am J Respir Crit Care Med 1999; 160: 1816-1823

24. Wills-Karp M, Luyimbazi J, Xu X, Schofield B, Neben TY, Karp CL, Donaldson DD. Interleukin-13: central mediator of allergic asthma. Science 1998; 282: 2258-2261.

25. Li L, Xia Y, Nguyen A, Lai YH, Feng L, Mosmann TR, Lo D. Effects of Th2 cytokines on chemokine expression in the lung: IL-13 potently induces eotaxin expression by airway epithelial cells. J Immunol 1999; 162: 2477-2487.

26. Chomarat P, Banchereau J. Interleukin- 4 and interleukin-13: their similarities and discrepancies. Int Rev Immunol 1998; 17: 1-52

27. Humbert M, Durham SR, Kimmitt P, et al. Elevated expression of messenger ribonucleic acid encoding IL-13 in the bronchial mucosa of atopic and nonatopic subjects with asthma. J Allergy Clin Immunol 1997; 99: 657-665.

28. Grunig G, Warnock M, Wakil AE, et al. Requirement for IL-13 independently of IL- 4 in experimental asthma [see comments]. Science 1998; 282 2261-2263.

29. Leckie MJ, ten Brincke A, Khan J, et al. Effects of an interleukin-5 blocking monoclonal antibody on eosinophils, airway hyperresponsiveness and the late asthmatic response. Lancet 2000; 356: 2144-2148.

30. Levitt RC, McLane MP, MacDonald D, et al. IL-9 pathway in asthma: new therapeutic targets for allergic inflammatory disorders. J Allergy Clin Immunol 1999; 103: S485-S491.

31. Gately MK, Renzetti LM, Magram J, Stern AS, Adorini L, Gubler U, Presky DH. The interleukin-12/interleukin-12-receptor system: role in normal and pathologic immune responses. Annu Rev Immunol 1998; 16: 495-521.

32. Gavett SH, O'Hearn DJ, Li X, Huang SK, Finkelman FD, Wills-Karp M Interleukin 12 inhibits antigen-induced airway hyperresponsivness, inflammation and Th2 cytokine expression in mice. J Exp Med 1995 182: $1527-1536$

33. Kim TS, DeKruyff RH, Rupper R, Maecker HT, Levy S, Umetsu DT. An ovalbumin-IL-12 fusion protein is more effective than ovalbumin plus free recombinant IL-12 in inducing a T helper cell type 1-dominated immune response and inhibiting antigen-specific IgE production. $J$ Immunol 1997; 158: 4137-4144.

34. Bryan S, O'Connor BJ, Matti S, et al. Effects of recombinant human interleukin-12 on eosinophils, airway hyperreactivity and the late asthmatic response. Lancet 2000; 356: 2149-2153
35. Kohno K, Kurimoto M. Interleukin 18, a cytokine which resembles IL-1 structurally and IL-12 functionally but exerts its effect independently of both. Clin Immunol Immunopatbol 1998; 86: 11-15.

36. Lack G, Bradley KL, Hamelmann E, et al. Nebulized IFN-gamma inhibits the development of secondary allergic responses in mice. $J$ Immunol 1996; 157: 1432-1439.

37. Boguniewicz M, Martin RJ, Martin D, Gibson U, Celniker A. The effects of nebulized recombinant interferon $\gamma$ in asthmatic airways. J Allergy Clin Immunol 1995; 95: 133-135.

38. Benjaponpitak S, Oro A, Maguire P, Marinkovich V, DeKruyff RH, Umetsu DT. The kinetics of change in cytokine production by CD4 T cells during conventional allergen immunotherapy. J Allergy Clin Immunol 1999; 103: $468-475$.

39. Durham SR, Ying S, Varney VA, et al. Grass pollen immunotherapy inhibits allergen-induced infiltration of CD4+ T lymphocytes and eosinophils in the nasal mucosa and increases the number of cells expressing messenger RNA for interferon- $\gamma$. J Allergy Clin Immunol 1996; 97: 1356-1365.

40. Pretolani M, Goldman M. IL-10: a potential therapy for allergic inflammation? Immunol Today 1997; 18: 277-280.

41. Borish L, Aarons A, Rumbyrt J, Cvietusa P, Negri J, Wenzel S. Interleukin10 regulation in normal subjects and patients with asthma.J Allergy Clin Immunol 1996; 97: 1288-1296.

42. John M, Lim S, Seybold J, Robichaud A, O'Connor B, Barnes PJ, Chung KF Inhaled corticosteroids increase IL-10 but reduce MIP-1 $\alpha$, GM-CSF and IFN- $\gamma$ release from alveolar macrophages in asthma. Am J Respir Crit Care Med 1998; 157: 256-262.

43. Zuany-Amorim C, Haile S, Leduc D, Dumarey C, Huerre M, Vargaftig BB Pretolani M. Interleukin-10 inhibits antigen-induced cellular recruitment into the airways of sensitized mice. I Clin Invest 1995; 95 2644-2651.

44. Akdis CA, BleskenT, Akdis M, Wuthrich B, Blaser K. Role of interleukin 10 in specific immunotherapy. I Clin Invest 1998; 102: 98-106.

45. Lim S, Crawley E, Woo P, Barnes PJ. Haplotype associated with low interleukin-10 production in patients with severe asthma. Lancet 1998; 352: 113 .

\section{Decreased prevalence of asthma among children with high exposure to cat allergen: relevance of the modified Th2 response}

\author{
Thomas A. E. Platts-Mills ${ }^{C A}$, John W. Vaughan, \\ Kevin Blumenthal, Judith A. Woodfolk and \\ Richard B. Sporik \\ Asthma \& Allergic Diseases Center, University \\ Health Systems, P.O. Box 801355 \\ Charlottesville, VA 22908-1355, USA
}

${ }^{\mathrm{CA}}$ Corresponding author

Tel: +1 8049245917

Fax: +1 8049245779

E-mail: tap2z@virginia.edu

\section{Introduction}

Although there are many possible explanations for the increase in asthma, they can be simplified to three. The first was proposed as early as 1980 and was based on epidemiology from a small group of countries in each of which the increase was related to dust mite sensitivity. ${ }^{1-3}$ This hypothesis focused on the increase in exposure that had occurred secondary to changes in housing and lifestyle. Over the next 10 years, it became obvious that increases had occurred in many countries and regions where dust mites were not the dominant indoor allergen. In Sweden and Finland, the increase was clearly 
Table 1. High concentrations of cat allergen are associated with decreased sensitization* but increased lgG (and lgG4) antibodies to Fel d 1

\begin{tabular}{lcccc}
\hline & \multicolumn{2}{c}{ Exposure to cat allergen Fel d 1 $(\mu \mathrm{g} / \mathrm{g})$} & $p$ \\
\cline { 2 - 4 } & $<1.6(n=75)$ & $1.7-23(n=75)$ & $23-3840(n=76)$ & \\
\hline Sensitization to cat & 12 & 19 & 10 & $\mathrm{~ns}$ \\
IgG antibody to cat & 13 & 24 & 10 & $\mathrm{n}$ \\
IgG antibody and sensitized & 10 & 6 & 31 & $<0.001$ \\
IgG antibody and not sensitized & 3 & 18 & 31 \\
\hline
\end{tabular}

* Total of 225 middle-school children aged 11 years. Sensitization assessed by skin tests and lgE antibody; data from references 4,17 and 20 .

present in areas where the primary allergens were derived from domestic animals. Similarly, in the southwest or mountain states of the USA, the relevant allergens are cat, dog and alternaria. ${ }^{4,5}$ Finally, it became clear that cockroaches were the most important allergen related to asthma in the major cities of the USA. ${ }^{6,7}$ Despite the involvement of different allergens, the time course of the increase appeared similar in many different countries (i.e. progressive over the period from about 1965 through 1995). Without evidence that exposure to these other allergens had increased, or a convincing explanation for an increase in cat or cockroach allergens, it became very unlikely that increasing exposure could explain all of the epidemic. However, exposure to indoor allergens may well have increased because of the increased time spent indoors.

The second group of hypotheses proposed that the increase could be explained by an alteration of immune responsiveness. ${ }^{8}$ These proposals focus on the many changes in lifestyle that could have shifted the balance between $\mathrm{T}$ helper cell (Th) 1 and Th2 responses. ${ }^{910}$ The hypothesis is that changes in diet, immunization, antibiotic use and/or a decrease in infectious diseases could have led to an increase in allergic disease. Both of these hypotheses imply that there has been an increase in allergy in general, in parallel with the increase in asthma. The actual data on increases in other allergic diseases are confusing. In England, several epidemiological studies have suggested that hayfever has increased as much as asthma. ${ }^{11}$ In the USA, it appears that hayfever increased progressively from 1920 onwards and was already affecting 16\% of the population by 1960 (i.e. before the major increase in asthma started). Similarly, comparisons of Hong Kong with Mainland China suggest that the increase in asthma in 'westernized' Hong Kong has not been matched by an increase in sensitization. If the increase in asthma represents a selective increase in lung disease or lung symptoms among the allergic population, then there are very different possible explanations.

\section{Immunity to common indoor allergens}

The evidence about a relationship between allergens and asthma is restricted to inhalant allergens and is based on either skin tests or serum IgE antibodies. Thus, there is very little epidemiological data relating to allergens that are not inhaled. In addition, there is no evidence based on T-cell responses or other isotypes of antibodies. At the time when immunoglobulin (Ig)E was discovered, it was already clear that the immune response in allergic individuals included other classes of antibodies, particularly IgG and $\operatorname{IgA} .^{12}$ Subsequently, it became clear that T-cell responses to purified allergens were common among patients with asthma and that these $T$ cells were characteristically Th2 in type.

Recently, several groups have suggested that responses to dust mite and other inhalants are dictated by events in utero. ${ }^{13,14}$ However, on critical analysis, the lymphocyte proliferation data on which that idea was based is unconvincing. In particular, there is very little data to show that cord blood responses are influenced by the exposure of the mother. ${ }^{15}$ Objective data on immune responses to inhalant allergens (i.e. serology or skin tests that can be repeated) is generally not apparent until about 2 years of age ${ }^{16}$ For allergens derived from dust mites, there is evidence from Australia, Europe, the United Kingdom and the USA that the prevalence of sensitization is directly related to exposure. ${ }^{1}$ Furthermore, for dust mites, it is possible to define a 'community' threshold for exposure above which sensitization to mites will be significantly related to asthma. Although the data for cockroach allergens is less extensive, it appears that both sensitization and the risk of asthma are also directly related to exposure to these insects. ${ }^{7}, 17$

By contrast, the evidence related to cat allergens is not simple. For several years there have been reports from Scandinavia that children raised in a house with a cat were less likely to have asthma. ${ }^{18,19}$ The obvious explanation is that allergic families avoid owning cats. However, the decreased sensitization of children 
living in a house with a cat is equally present among children who are atopic as judged by other skin tests. ${ }^{17}$ Recently, we have shown that many of the children who are exposed to high concentrations of cat allergen at home have IgG antibodies to Fel d 1 (Table 1). Furthermore, these IgG antibodies include a large proportion of $\operatorname{IgG}_{4}$, an isotype that is fully dependent on interleukin- $4 .^{20}$ Thus, this immune response to Fel d 1 in children who are not skin-testpositive to cat, and not symptomatic, we refer to as a 'modified Th2 response'. This evidence that high exposure to an allergen can induce tolerance has many implications. These include: (i) that the response to high-dose animal allergen is not a Th1 response; (ii) that increasing exposure to cat allergens cannot explain the increase in asthma since higher exposure gives rise to tolerance; and (iii) that it is unlikely that changes in 'immune responsiveness' could have produced the same progressive increase in asthma in countries where cat allergen is dominant as in countries where mite is dominant.

\section{Have lifestyle changes altered the threshold for wheezing?}

The increase in asthma prevalence over a 40-year period looks similar to the increase in type 2 diabetes, hypertension or obesity, rather than any known epidemic of infectious disease. In the USA but not in other countries, this increase has been most severe among individuals living in poverty and, in particular, among African Americans living in the cities. It is therefore essential to examine changes in lifestyle in the cities that could be relevant to a progressive change over 40 years. There are three lines of evidence that suggest that lifestyle changes, including a decline in physical activity, could have lowered the threshold for wheezing.

1. Bronchial smooth muscle requires regular full extension, or it will start to contract at a shorter length. ${ }^{21}$ In keeping with that, normal individuals will develop broncho hyper-responsiveness (BHR) if they are prevented from taking deep breaths. ${ }^{22}$

2. Recent reports that obesity is a risk factor for both prevalent and incident asthma. ${ }^{23,24}$ While it is possible that hormonal or other effects related to obesity influence 'inflammation' in the lungs, the more likely explanation is that obesity is a surrogate for decreased activity.

3 . The lifestyle changes that characterize poverty in the cities of the USA (and could explain the difference from poverty elsewhere in the world) are poor diet, increased sedentary time, and a decline in physical activity. ${ }^{25}$

In some countries, particularly China and the USA, the evidence suggests that the increase in asthma has been primarily an increase in wheezing among allergic individuals. If this is so, then the increase in asthma could be seen as a decrease in the threshold for wheezing. Taking the evidence together, we would ask has decreased physical activity or prolonged time spent inactive lowered the threshold for wheezing? This effect could be primarily physiological (i.e. related to smooth muscle function); the alternative explanation would be that prolonged exercise plays a role in decreasing inflammation or accelerating the healing of inflammatory foci.

\section{Conclusion}

The evidence that children raised in a house with a cat are less likely to become allergic to cat allergens has major implications for understanding the role of immune responses to allergens in the increase in asthma. First, it is clear that the dose response to animal dander is different from that to mite or cockroach, thus the effect of increasing exposure would not be the same. Second, the finding that high exposure to cat allergen can induce a modified Th2 response strongly argues against the hypothesis that a shift from Th1 to Th2 could be the basis for the increase in asthma. Indeed, in our studies, most non-allergic individuals have no serological evidence that they have made an immune response. The results imply that the true explanation for the increase in asthma lies elsewhere. Given the evidence about obesity and the physiological requirement of bronchial smooth muscle for full extension, it becomes increasingly possible that the decline in physical activity has contributed to a progressive lowering of the threshold for wheezing among allergic children.

ACKNOWLEDGEMENTS. Supported by NIH Grant Nos. AI-20565 and NIEHS/ NIAID 34607

\section{References}

1. Platts-Mills TAE, Vervloet D, Thomas WR, Aalberse RC, Chapman MD (CoChairmen). Indoor allergens and asthma. Third International Workshop, Cuenca Spain. J Allergy Clin Immunol 1997; 100: S1-S24.

2. Platts-Mills TAE, Mitchell EB, Tovey EB, Chapman MD, Wilkins SR. Airborne allergen exposure, allergen avoidance and bronchial hyperreactivity. In: Kay AB, Austen KF, Lichtenstein LM, eds. Asthma: Physiology, Immunopharmacology and Treatment, Third International Symposium. London: Academic Press, Inc., 1984: 297-314.

3. Platts-Mills TAE, Tovey ER, Mitchell EB, Moszoro H, Nock P, Wilkins SR. Reduction of bronchial hyperreactivity during prolonged allergen avoidance. Lancet 1984; 2: 675-678.

4. Sporik RB, Ingram JM, Price W, Sussman JH, Honsinger RW, Platts-Mills TAE. Association of asthma with serum IgE and skin-test reactivity to allergens among children living at high altitude: Tickling the dragon's breath. Am J Respir Crit Care Med 1995; 151: 1388-1392.

5. Halonen M, Stern DA, Wright AL, Taussig LM, Martinez FD. Alternaria as a major allergen in children raised in a desert environment. Am J Resp Crit Care Med 1997; 155: 1356-1361.

6. Call RS, Smith TF, Morris E, Chapman MD, Platts-Mills TAE. Risk factors for asthma in inner city children. J Pediatr 1992; 121: 862-866.

7. Rosenstreich DL, Eggleston P, Kattan M, et al. The role of cockroach allergy and exposure to cockroach allergen in causing morbidity among inner-city children with asthma. N Engl J Med 1997; 336: 1356-1363. 
8. Seaton A, Godden DJ, Brown K. Increase in asthma: a more toxic environment or a more susceptible population? Thorax 1994; 49: 171-174.

9. Holgate ST. The epidemic of allergy and asthma. Nature $1999 ; 402(6760$ Suppl): B2-B4

10. Holt PG, Macaubas C, Stumbles PA, Sly PD. The role of allergy in the development of asthma [review]. Nature 1999; 402: B12-B17.

11. Strachan DP, Harkins LS, Johnson ID, Anderson HR. Childhood antecedents of allergic sensitization in young British adults. J Allergy Clin Immunol 1997; 99: 6-12.

12. Ishizaka K, Ishizaka T, Hornbrook MM. Physico-chemical properties of human reaginic antibody. IV. Presence of a unique immunoglobulin as a carrier of reaginic activity. J Immunol 1966; 97: 75-85.

13. Prescott SL, Macaubas C, Smallacombe T, Holt BJ, Sly PD, Loh R, Holt PG Reciprocal age-related patterns of allergen-specific T-cell immunity in normal vs. atopic infants. Clin Exp Allergy 1998; 28: 39-44.

14. Miles EA, Warner JA, Jones AC, Colwell BM, Bryant TN, Warner JO Peripheral blood mononuclear cell proliferative responses in the first year of life in babies born to allergic parents. Clin Exp Allergy 1996; 26: 780-788.

15. Platts-Mills TAE, Woodfolk JA. Cord blood proliferative responses to inhaled allergens: is there a phenomenon? [editorial]. J Allergy Clin Immunol 2000; 106: 441-443

16. Rowntree S, Cogswell JJ, Platts-Mills TAE, Mitchell EB. Development of IgE and IgG antibodies to food and inhalant allergens in children at risk of allergic disease. Arch Dis Child 1985; 60: 727-735.

17. Sporik R, Squillace SP, Ingram JM, Rakes G, Honsinger RW, Platts-Mills TAE. Mite, cat and cockroach exposure, allergen sensitization, and asthma in children: a case-control study of three schools. Thorax 1999; 54: 675-680.

18. Hasselmar B, Aberg N, Aberg B, Eriksson B, Bjorksten B. Does early exposure to cat or dog protect against later allergy development? Clin Exp Allergy 1999; 29: 611-617.

19. Svane C, Jarvis D, Chinn S, Burney P. Childhood environment and adult atopy: results from the European Community Respiratory Health Survey. J Allergy Clin Immunol 1999; 103: 415-420.

20. Platts-Mills T, Vaughan J, Squillace S, Woodfolk J, Sporik R. Sensitisation, asthma, and a modified $\mathrm{Th} 2$ response in children exposed to cat allergen: a population-based cross-sectional study. The Lancet 2001; 357: $752-756$

21. Fredburg JJ, Inouye DS, Mijailovich SM, Butler JP. Perturbed equilibrium of myosin binding in airway smooth muscle and its implications in bronchospasm. Am J Resp Crit Care Med 1999; 159: 959-967.

22. Skloot G, Permutt S, Togias A. Airway hyperresponsiveness in asthma. $J$ Clin Invest 1995; 96: 2393-2403.

23. Luder E, Melnik TA, DiMaio M. Association of being overweight with greater asthma symptoms in inner city black and Hispanic children. $J$ Peds 1998; 132: 699-703.

24. Camargo CA, Weiss ST, Zhang S, Willett WC, Spetzer FE, Prospective study of body mass index, weight change, and risk of adult-onset asthma in women. Arch Intern Med 1999; 159: 2582

25. Platts-Mills TAE, Woodfolk JA, Chapman MD, Heymann PW. Changing concepts of allergic disease: the attempt to keep up with real changes in lifestyles [review]. J Allergy Clin Immunol 1996; 98: S297-S306.

\section{Atopic dermatitis: a paradigmatic allergic skin disease}

\section{Thomas Bieber}

Department of Dermatology,

Friedrich-Wilhelms-University,

Sigmund-Freud-Straße 25, D-53105 Bonn, Germany

Tel: +492282874388

Fax: +492282874881

E-mail: thomas.bieber@meb.uni-bonn.de

\section{Introduction}

Atopic dermatitis (AD) is a chronic inflammatory skin disease clinically and histologically highly similar to allergic contact dermatitis. Recently, it has been proposed to subdivide $\mathrm{AD}$ into two distinct forms: the extrinsic form (occurring in the context of sensitization toward environmental allergens), and the intrinsic form (occurring in the absence of any typical atopical background). ${ }^{1}$ While the pathophysiology of the intrinsic form remains almost elusive, tremendous progress has been made in the understanding of the extrinsic form. Thus, since IgE plays a major role in other atopic diseases such as asthma and rhinitis, it is assumed that, in this extrinsic form, immunoglobulin $\mathrm{E}$ (IgE) also mediated the specificity of the inflammatory conditions in the skin.

\section{Presence of IgE-bearing dendritic cells in the skin of patients with AD}

The emergence of extrinsic AD (i.e. a cell-mediated inflammation) in atopic patients (i.e. individuals prone to have increased IgE production and to develop IgE-mediated hypersensitivity reactions) remained puzzling until the mid-1980s, when the presence of IgE molecules on the surface of Langerhans cells (LC) from patients presenting AD was first reported. ${ }^{2,3}$ A new pathophysiological concept was proposed in which LC and inflammatory dendritic epidermal cells (IDEC) ${ }^{4}$ armed with allergen-specific IgE would trigger an eczematous inflammation.

\section{Molecular structure, regulation and function of $F c_{\varepsilon} R I$ on human dendritic cells}

The identity of the relevant IgE-binding structure of cutaneous dendritic cells (DC) was unclear for some years, until other workers and myself demonstrated the presence of the high-affinity receptor for IgE (FceRI) on these cells as well as on other antigen presenting cells (APC), including monocytes, and circulating DC..$^{5-7}$ It also became clear that FceRI on APC lacks the classical $\beta$-chain and thus, in contrast to effector cells of anaphylaxis (i.e. mast cells and basophils that express an $\alpha, \beta, \gamma 2$ conformation), APC display an $\alpha, \gamma 2$ conformation that implies profound functional consequences. Moreover, its expression and the function may be highly variable, depending on the microenvironment. ${ }^{8}$ However, the highest expression is specifically observed in $\mathrm{AD}$ skin. ${ }^{9}$ One may speculate that FceRI ligation on APC putatively triggers the synthesis and release of mediators that may initiate a local inflammatory reaction, as has been demonstrated for mast cells.

Fc $\varepsilon$ RI/IgE-mediated allergen uptake and subsequent antigen presentation has been attributed a key event in the pathogenesis of atopic dermatitis. ${ }^{10}$ Using this kind of antigen uptake, APC may, in the presence of antigenspecific IgE, increase their presenting capacity up to 100-fold. ${ }^{11}$ This mechanism, also known as 'antigen focusing' or 'facilitated antigen presentation', has been shown effective by different research groups in different cell systems. The observation that the 


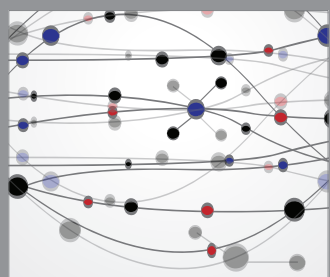

The Scientific World Journal
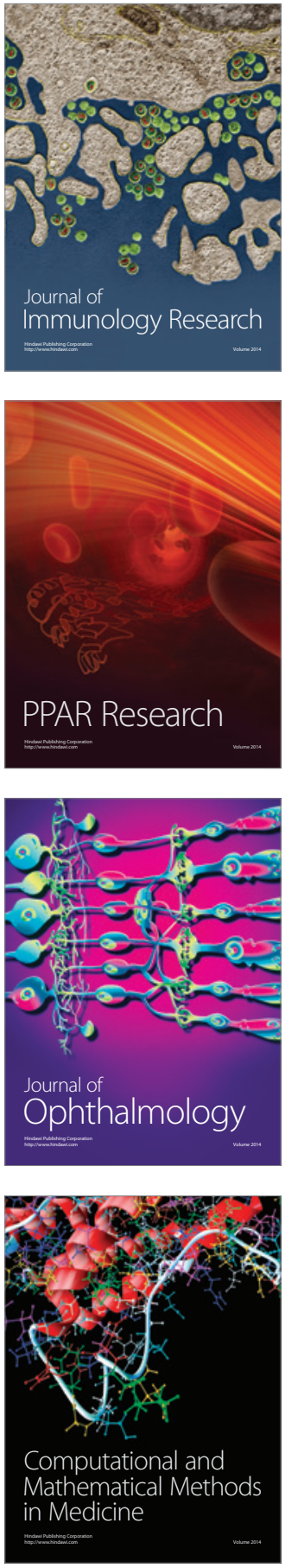

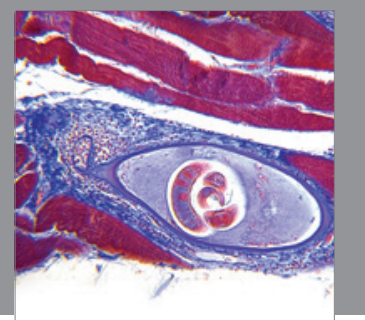

Gastroenterology

Research and Practice
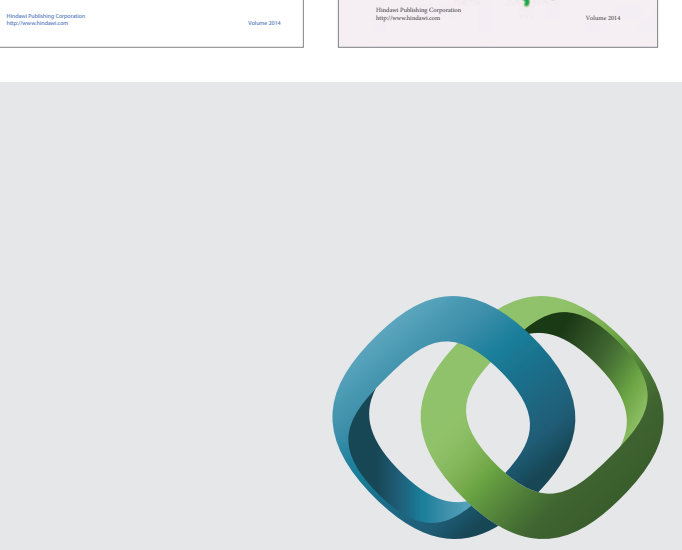

\section{Hindawi}

Submit your manuscripts at

http://www.hindawi.com
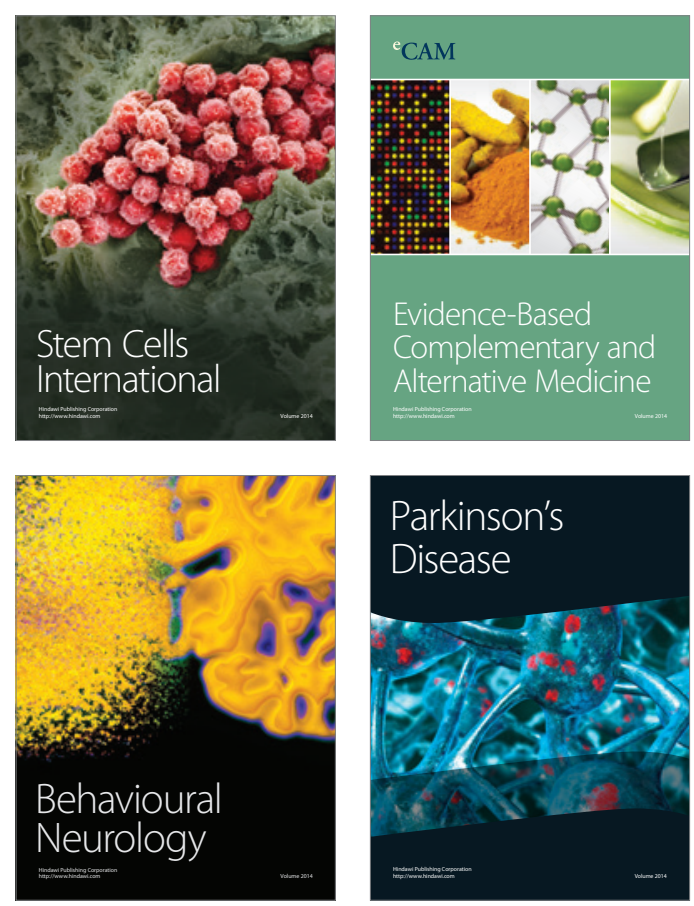

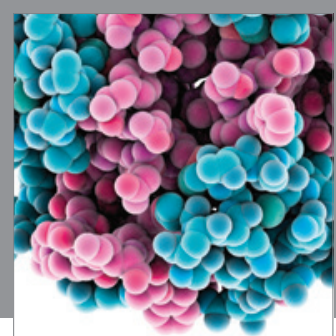

Journal of
Diabetes Research

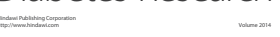

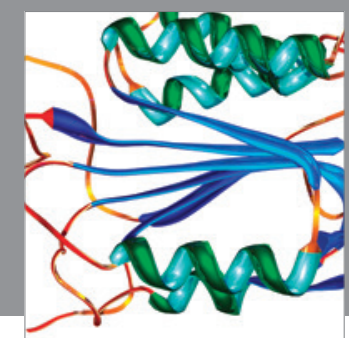

Disease Markers
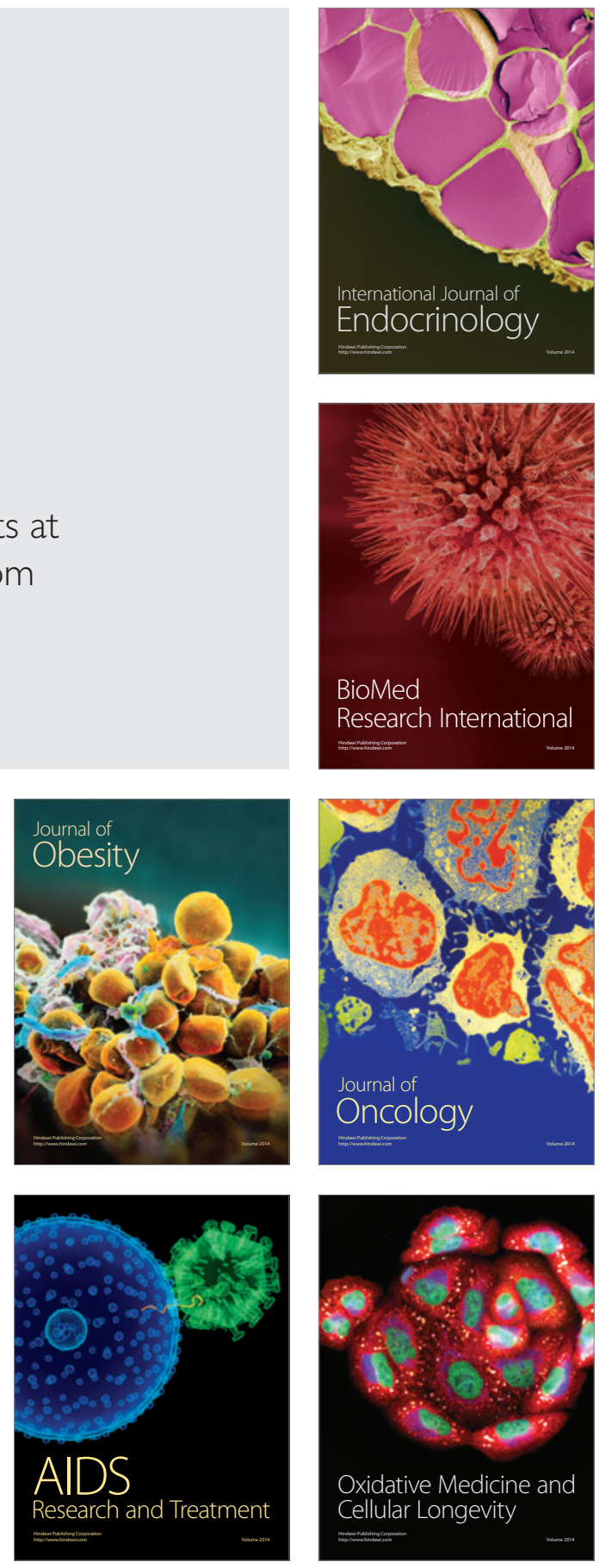